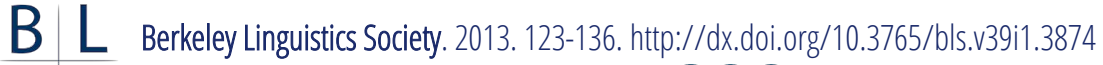 Published by the Linguistic Society of America
}

\section{Elucidating Nominal Structure in Articleless Languages: A Case Study of Tatar ${ }^{1 *}$}

\author{
EKATERINA LYUTIKOVA ${ }^{1} \&$ ASYA PERELTSVAIG ${ }^{2}$ \\ Moscow State University ${ }^{1}$; Sholokhov Moscow State University for Humanities ${ }^{1}$; \\ Stanford University ${ }^{2}$
}

\section{$1 \quad$ Introduction}

The central question addressed by this paper is whether languages without articles have the same highly articulated functional architecture in noun phrases, including the DP projection. Previous studies focused on Slavic languages (but see Bošković and Şener 2012 on Turkish); some scholars (cf. Progovac 1998, Engelhardt \& Trugman 1998, Rutkowski 2002, inter alia) argued in favor of the DP projection, while Bošković (2005, 2008, 2009, 2010; Bošković and Şener 2012) argued against it. Pereltsvaig $(2006,2007,2013)$ argued that while some nominals in Russian and other articleless Slavic languages are DPs, others are Small Nominals (SNs) of different sizes. In this paper, we provide novel evidence for the latter position based on another Turkic language, Tatar (spoken by over 5 million in Tatarstan, Russia). Drawing on our fieldwork on one sub-dialect of Tatar (spoken in the village of Kutlushkino), we show that different syntactic constructions call for nominals of different sizes. Moreover, we argue that Differential Object Marking (DOM) in Tatar-unlike in other Turkic languages such as Turkish or Sakha - can only be explained in terms of the amount of

\footnotetext{
1* Our many thanks to Pavel Graschenkov, Olga Kagan, Ora Matushansky, Sergei Tatevosov, Yakov Testelets for helpful discussions, comments, and suggestions. We are also grateful to our Tatar consultants for their invaluable help. All errors are solely ours. This research has been partially supported by Russian Scientific Foundation (РНФ, grant №14-18-03270 "Word order typology, syntax - prosody interface and information structure in the world's languages" at Sholokhov Moscow State University for Humanities), and Russian Foundation for Basic Research (РФФИ, grant №13-06-00884).
} 


\section{Ekaterina Lyutikova \& Asya Pereltsvaig}

functional architecture in the object: DP objects receive structural (accusative) Case, as in (1a), while SNs (i.e. NPs or NumPs) remain Caseless, as in (1b).

(a)
a.
Marat [DP mašina-nı] sat
Marat car-ACC se
'Marat bought a/the car.'
Marat [NP/Nump mašina]
sat-1p
al-d1.
take-PST
b. Marat [NP/Nump mašina]
sat-1p
al-d1.
'Marat bought a car/cars.'

Thus, we rule out alternative analyses based on distinct positions of accusative and unmarked objects or on the semantic interpretation of the object. More generally, we propose that only DPs must receive structural case while SNs are not subject to such Case licensing requirements and may remain morphologically Caseless.

The rest of this paper is organized as follows. In section 2, we show that nominals in Tatar come in different sizes: some are DPs and others are Small Nominals (in the sense of Pereltsvaig 2006). In section 3, we lay out our proposal for DOM in Tatar that accusative-marked (ACC) objects in Tatar are DPs, whereas unmarked objects are Small Nominals. In sections 4 and 5 we argue against the Semantic and Positional Alternatives, respectively. Section 6 concludes the paper.

\section{$2 \quad$ Noun Phrases in Tatar Come in Different Sizes}

We assume that the strict ordering of nominal suffixes reflects the order of functional projections in the noun phrase, following Baker's Mirror Principle (Baker 1985). These suffixes include - in the order away from the noun root - the plural suffix -lar in Num ${ }^{\circ}$, the ezafe- 2 marker $-l /-s l$ in Poss ${ }^{\circ}$, the ezafe-3 marker such as $-\imath m$ in $\mathrm{D}^{\circ}$ (note that ezafe- 2 and ezafe- 3 markers are incompatible with each other, for reasons that are outside the scope of this paper), and case suffix such as - $a$ for dative. ${ }^{2}$ The word bala-lar-ım- $a$ 'to my children' is analyzed as [KP $a$ [DP $-l m$ [NumP lar [NP [N bala-]]]]]. Although Tatar noun phrases are maximally KPs, not all noun phrases are fully projected. Various constructions involve nominals of different sizes: $\mathrm{N}^{\circ}, \mathrm{NP}$, NumP, DP, or KP can be embedded in different constructions.

For instance, the nominal element in complex predicate constructions (CPCs), as in (2a), cannot be ACC-marked, as shown in (2b). Pronouns cannot serve as the nominal element in a CPC (2c); nor does it have room for the plural marker -lar $(2 \mathrm{~d})$ or modifiers of any kind $(2 \mathrm{e})$.

\footnotetext{
2 The various suffixes in Tatar are subject to vowel harmony, as well as occasional nasal and/or voicing assimilation.
} 


\section{Elucidating Nominal Structure in Tatar}

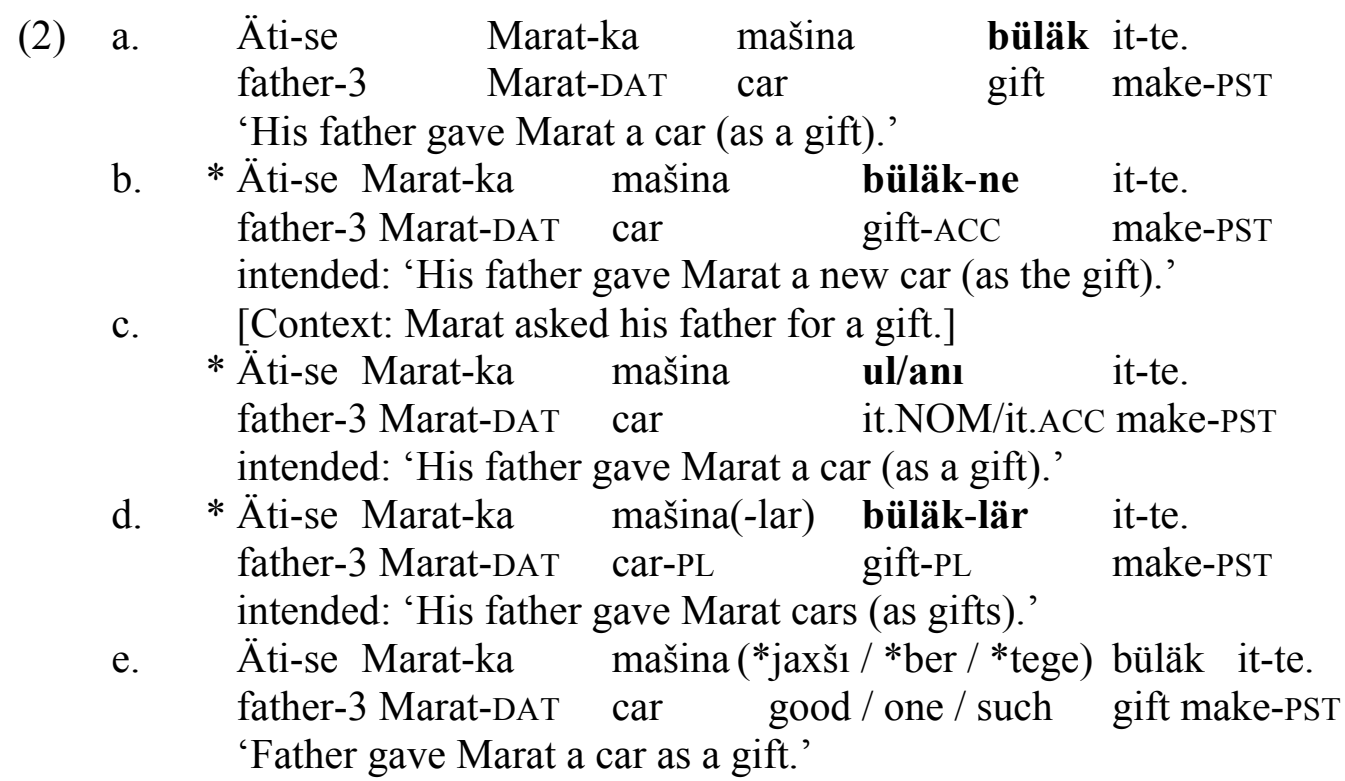

Let us now consider nominal (ezafe) constructions. There are three such constructions in Tatar, known as ezafe-1, ezafe-2, and ezafe-3. As we show below, ezafe- 1 embeds a bare $\mathrm{N}^{\circ}$, ezafe- 2 embeds a NumP, and ezafe- 3 embeds a $\mathrm{KP}$ (or a genitive-marked DP).

The embedded element of ezafe-1, which is used typically for materials, is a bare noun, as in (3a). Like the nominal component in CPCs, it cannot be a pronoun (3b), nor can it contain the plural marker -lar (3c), or any modifiers (3d).

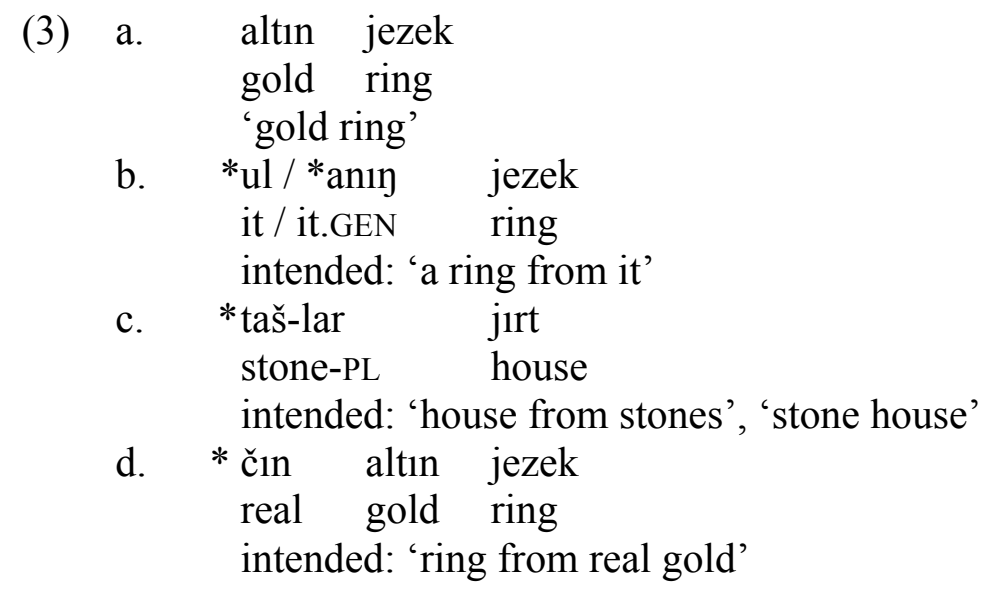

In contrast, the embedded element of ezafe- 2 is a NumP: like the nominals considered above, it cannot be a pronoun (4a), nor a proper noun (4b). However, it can include the plural marker -lar (4c) or certain modifiers (4d). (The ezafe-2 marker is the suffix glossed here as ' 3 ' for 3rd person; it does not show 


\section{Ekaterina Lyutikova \& Asya Pereltsvaig}

agreement.)

(4)
a. *min däftär-em
I notebook-1SG
intended: 'my notebook'
b. * zefär ata-s1
Zufar dad-3
(Grashchenkov 2007)
intended: 'Zufar's dad'
c. kırsak-l1 xatın-nar kijem-e
belly-ATR woman-PL clothing-3
'clothing for pregnant women'
d. bala-lar xastaxanä-se tabib-1
child-PL hospital-3 doctor-3
'a doctor in a children's hospital'
\# 'a doctor of children's hospitals'

Unlike the ezafe-2 marker, the marker of ezafe-3 shows person and number agreement with the possessor, which can be a pronoun or a proper name, unlike with ezafe-2. We propose that the embedded nominal in ezafe-3 is a genitivemarked DP, or a KP.

(5) a. minem däftär-em

I.GEN notebook-1SG

'my notebook'

b. Marat-nı̀ däftär-e

Marat-GEN notebook-3

'Marat's notebook'

As it turns out, ezafe- 3 itself is a DP; hence, can be embedded only in ezafe- 3 but not in ezafe- 2 .

(6) a. ezafe-2:

*[[ukuč1-nı̀ däftär-lär-e] papka-s1]

student-GEN notebook-PL-3 folder-3

'folder for student's notebooks'

b. ezafe-3:

[[ukuč1-n1y däftär-lär-e-ney] papka-s1]

student-GEN notebook-PL-3-GEN folder-3

'folder for student's notebooks'

In addition to the constructions described above, Tatar also has a number of attributivizer constructions. Here, only two such attributivizers, which turn a nominal into an attributive modifier, will be considered. Attributivizer $-l l$ selects a bare NP, while attributivizer $-g l$ selects a KP, specifically a locative-marked one. 
(7) a. $\quad[\mathrm{NP} \ldots]-l l \mathrm{~N}$

b. $\quad[\mathrm{KP}[\mathrm{DP} \ldots . . \mathrm{LOC}]-g l \mathrm{~N}$

The nominal selected by attributivizer $-l l$ cannot be a pronoun ( $8 \mathrm{a})$, cannot contain the plural marker -lar (8b), but unlike with the nominal element in CPCs or the embedded nominal in ezafe-1, it can contain certain modifiers (8c).
a. *ul-11 čaška
it-ATR cup
intended: 'a cup with it' (e.g. a blue flower)
b. *kük čäčäk-lär-le čaška
blue flower-PL-ATR cup
intended: 'a cup with blue flowers
$\begin{array}{lll}\text { c. kük čăčäk-le } & \text { čaška } \\ \text { blue flower-ATR } & \text { cup } \\ \text { 'a cup with a blue flower' OR 'a cup with blue flowers' }\end{array}$

In contrast, the nominal selected by attributivizer $-g l$ is a full-fledged KP: it can be a locative-marked pronoun (9a) or a proper name (9b), even ezafe-3 (9c), which as we have shown above is a DP. It can also contain the plural marker -lar (9d) or modifiers $(9 \mathrm{e})$.

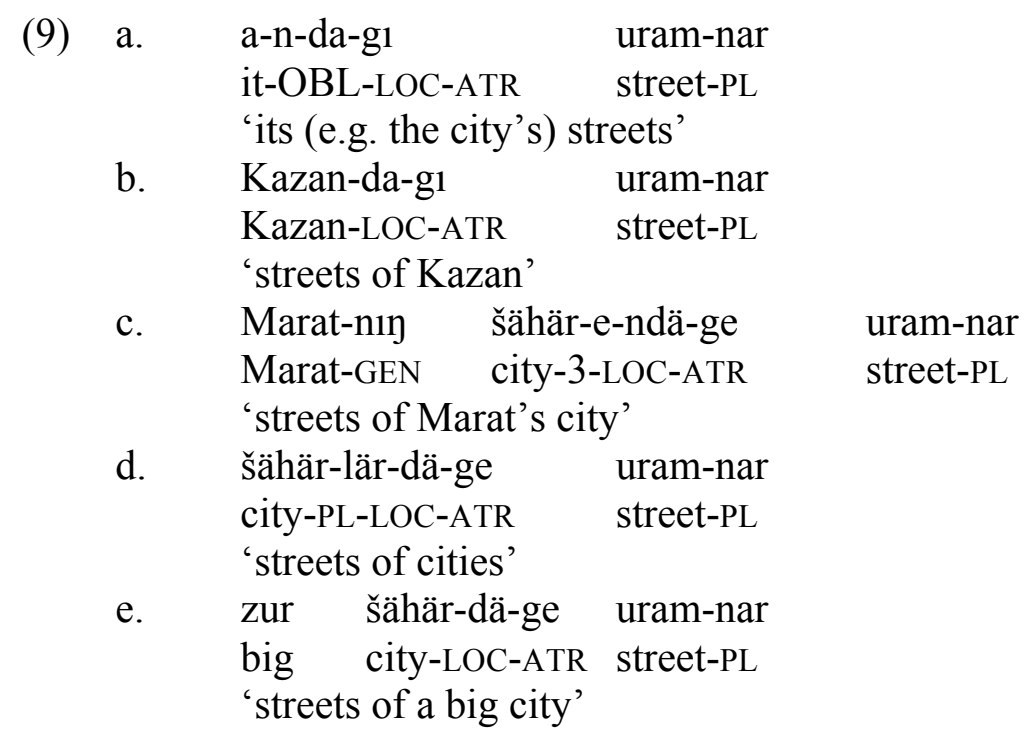




\section{Ekaterina Lyutikova \& Asya Pereltsvaig}

\section{Our Proposal: Structural Analysis of DOM in Tatar}

In the preceding section, we have shown that nominals in Tatar can be projected fully or can be Small Nominals. Here, we argue that the same contrast accounts for the Differential Object Marking (DOM) phenomenon in the language. Our proposal is that the accusative case marker $-n l$, as in (10a), attaches to a DP. Unmarked objects are thus Small Nominals. More generally, we hypothesize that only DPs must receive structural case, while SNs are not subject to such Case licensing requirements and may remain morphologically Caseless. Three arguments are discussed below in support of this analysis.

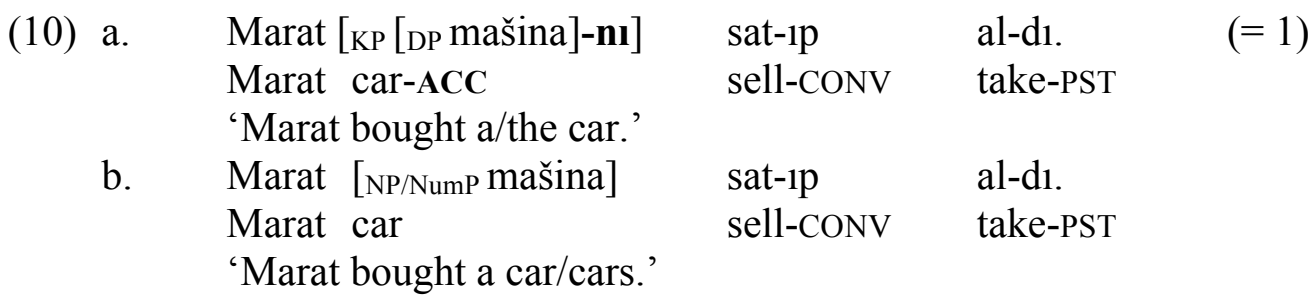

The first piece of evidence that suggests that ACC-marked and unmarked objects in Tatar are structurally different involves coordination: as shown in (11a), the two types of objects cannot be coordinated. If the unmarked object precedes the ACC-marked one, as in (11b), the sentence is grammatical, but such examples involve phrasal case marking, further illustrated in (11c).

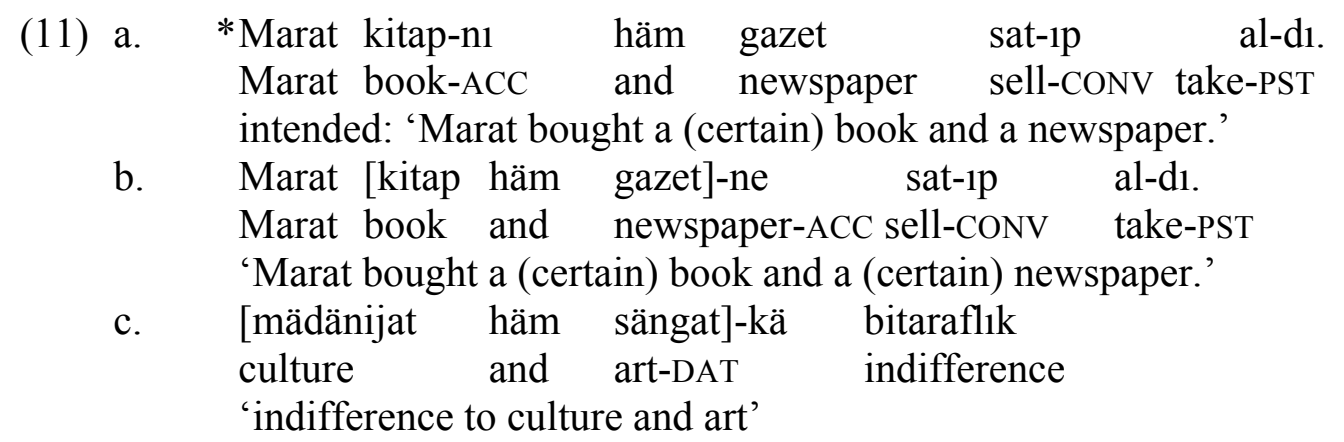

The second argument in favor of our proposal comes from the fact that minimal pairs such as (10) are not always possible. Accusative marker is required whenever the object is or contains some element typically associated with the DPlevel. Thus, objects which are pronouns (12a), proper names (12b), or ezafe-3 constructions (12c), as well as objects containing a strong quantifier, such as här 'every' or ike...dä 'both' (12d), or a demonstrative bu 'this' or šul 'that' (12e), must be marked accusative. 
(12) a. Marat a-lar-*(n1) kür-de.

Marat he-PL-ACC see-PST

'Marat saw them.'

b. Alsu Marat-*(nı) čakır-dı.

Alsu Marat-ACC invite-PST

'Alsu invited Marat.'

c. Marat Ramil-ney mašina-s1-*(n) sat-1p al-d1.

Marat Ramil-GEN car-3-ACC sell-CONV take-PST

'Marat bought Ramil's car.'

d. Marat här birem-*(ne) čiš-te.

Marat every problem-ACC solve-PST

'Marat solved every problem.'

e. Marat bu mašina-*(n1) sat-1p al-d1.

Marat that car-ACC sell-CONV take-PST

'Marat bought that car.'

Our third argument in support of the structural analysis of DOM in Tatar is that unmarked objects fit the profile of a Small Nominal, as described in Pereltsvaig (2006). First, they cannot have an individuated, specific, partitive, or anaphoric interpretation. For example, only (13a) is an appropriate continuation to 'We have a cat and a dog':
a. Min kübesenčä et-ne jarat-a-m.
I more dog-ACC like-PRS-1SG
'I like the dog more.'
b. Min kübesenčä et jarat-a-m.
I more dog like-PRS-1SG
'I like $\{$ a dog/dogs $\}$ more.'

Second, unmarked objects cannot have wide scope in relation to other quantifiers (14a) or negation (14b).

(14) a. Här ukučı ike kitap ukı-dı.

every student two book read-PST

b. Marat ike kitap uk1-ma-d1.

Marat two book read-NEG-PST

'Marat didn't read two books.' Neg $>2, * 2>$ Neg

While unmarked objects may contain the plural marker -lar, if this marker is absent, the object has a number-neutral interpretation (cf. Pereltsvaig 2013, forthcoming), as in (15a). The presence of the plural marker -lar entails a plural 
interpretation, as in (15b). In contrast to unmarked objects, with ACC-marked objects the absence of plural marker -lar does not entail number-neutrality, as shown in (15c).

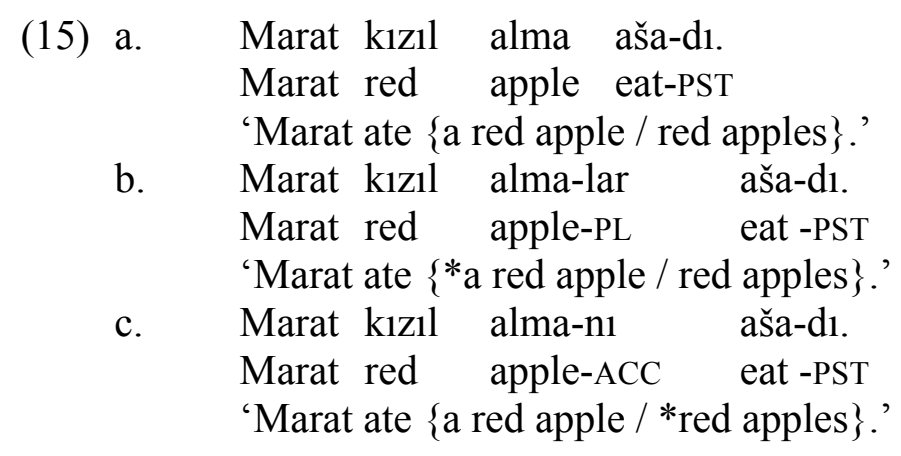

Finally, unlike ACC-marked objects, unmarked objects cannot control syntactic anaphora: they cannot serve as controllers of PRO, as shown in (16a), or antecedents of reflexives or reciprocals, as shown in $(16 \mathrm{~b}, \mathrm{c})$. It should be noted that the ungrammaticality of unmarked objects as controllers of PRO or antecedents of reflexives or reciprocals is preserved regardless of word order permutations; space limitations prevent us from presenting all the possible word order variations.

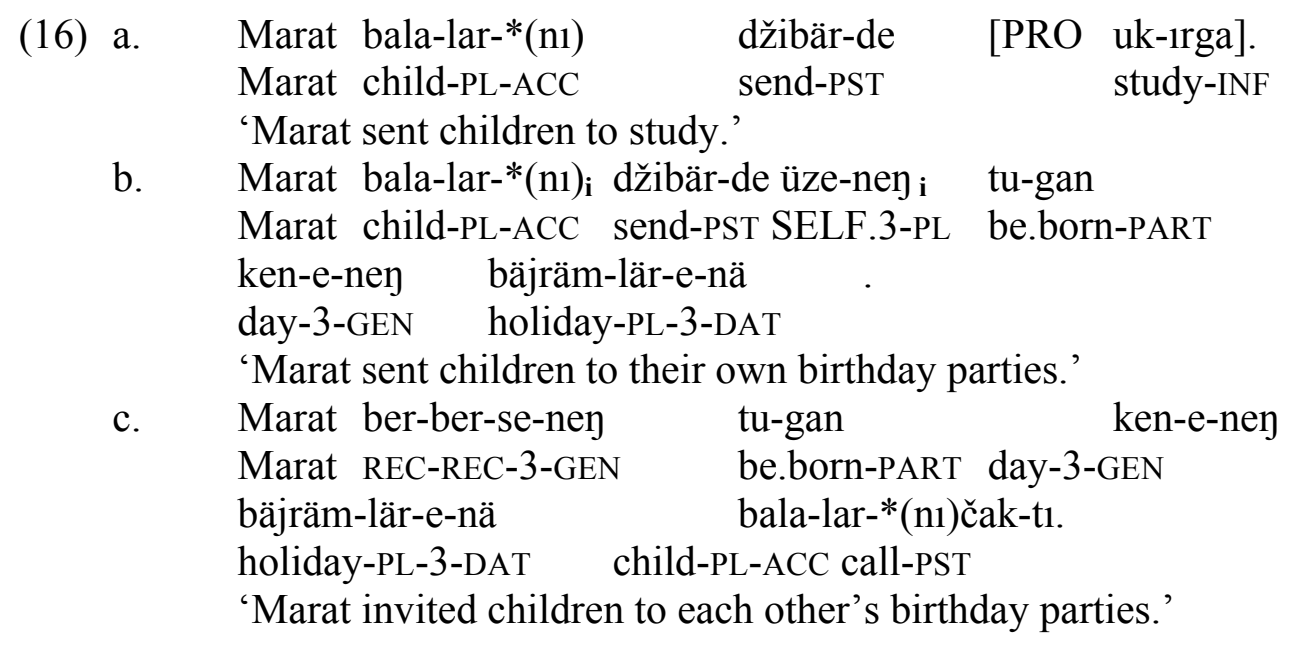

To conclude, ACC-marked and unmarked objects are structurally distinct, as suggested by the fact that they cannot be coordinated. DP objects must be accusative marked, while unmarked objects have all the properties of Small Nominals.

In the following sections, we will consider and dismiss two alternative analyses proposed for DOM in other Turkic languages (and some non-Turkic languages as well): the Semantic Alternative and the Positional Alternative. 


\section{Elucidating Nominal Structure in Tatar}

\section{Semantic Alternative}

One alternative analysis, which has been proposed for DOM in Turkish by Enç (1991), as well as for DOM in Hebrew by Danon (2006), correlates the accusative case marking or its absence with the semantics of the object rather than its functional structure. According to this group of analyses, ACC-marked objects are referential, specific, or definite, depending on the particular proposal, whereas unmarked objects are not. As mentioned above, unmarked objects in Tatar have a non-individuated, non-specific, non-partitive, non-anaphoric interpretation. Could it be that the same analysis applies in Tatar? We do not think so.

The data that challenges the Semantic analysis for Tatar involves ezafe-3 construction. As mentioned above, an object which is an ezafe-3 construction must receive structural (accusative) case. However, it may simultaneously receive a non-specific interpretation and take narrow scope in relation to other quantifiers or negation, as shown in $(17 \mathrm{a}, \mathrm{b})$. For example, the sentence in $(17 \mathrm{a})$ can be interpreted as 'There are two specific poems by Tukay that every student read' or as 'Every student read some two poems by Tukay'. Similarly, the sentence in (17b) can be interpreted as 'There is a photo of Alsu that Marat didn't see' or as 'It is not the case that Marat saw a/any photo of Alsu'. In both examples, it is the second interpretation that is unexpected under the Semantic Alternative.

(17) a. Här ukučı Tukaj-nıy ike šigır-e-*(n) uk1-d1.

every studentTukay-GEN two poem-3-ACC read-PST 'Every student read two poems by Tukay.'

$2>\forall$ or $\forall>2$

b. Marat Alsu-nı̀ fotografia-se-*(n) kür-me-de.

Marat Alsu-GEN photo-3-ACC see-NEG-PST

'Marat didn't see a photo of Alsu.'

$\exists>\mathrm{Neg}$ or $\mathrm{Neg}>\exists$

Because the presence of accusative case marking does not guarantee a referential, specific, or definite interpretation, we must reject the Semantic Alternative.

\section{$5 \quad$ Positional Alternative}

In the preceding section, we have shown that DOM in Tatar cannot be accounted for purely in terms of the semantics of the object. In this section, we considerand also reject - another alternative theory that places the burden of explanation on the position of the object in the clausal structure. According to this approach, unmarked objects appear in $v \mathrm{P}$, whereas ACC-marked objects appear higher, outside $v \mathrm{P}$. For example, an analysis along those lines has been proposed for 
DOM in another Turkic language, Sakha, by Baker \& Vinokurova (2010: 599602). Furthermore, unmarked objects have been analyzed as pseudo-incorporated into the verb (cf. Massam 2001, Baker 2009). In what follows, we show that although this approach may work for other languages, it is not applicable to Tatar.

The first problem for the Positional Alternative is similar to the challenge we described above for the Semantic Alternative: while unmarked objects behave roughly as expected (i.e. they appear relatively low in the clausal structure), ACCmarked objects do not. In particular, they can appear inside the $v \mathrm{P}$ boundary marked by (manner) adverbs such as tiz 'quickly'. In this respect, Tatar is genuinely different from Sakha, where such sentences are ungrammatical. (The Sakha example (18b) below is from Baker \& Vinokurova 2010: 602, their (12b); it is said to be grammatical if the object has contrastive focus.)

(18) a. Tatar

Marat tiz botka-nı aša-dı.

Marat quickly porridge-ACC eat-PST

'Marat ate porridge quickly.'

b. Sakha

*Masha türgennik salamaat-y sie-te.

Masha quickly porridge-ACC eat-PAST.3sS

'Masha ate porridge quickly.'

Moreover, although unmarked objects in Tatar have some semantic properties associated with pseudo-incorporated nominals (e.g. their obligatory nonreferential interpretation, obligatory narrow scope, and possible number-neutrality), they do not seem to have a particularly tight syntactic connection to the verb. In fact, if anything is pseudo-incorporated in Tatar, it is the the nominal components in CPCs, considered above. First, the nominal component in CPCs and unmarked objects behave differently in causative constructions: in causative constructions based on CPCs, the causee is marked accusative, as shown in (19a). In contrast, in causative constructions with either ACC-marked or unmarked objects, the cause is ablative, rather than accusative, as shown in $(19 \mathrm{~b}, \mathrm{c})$. This shows that nominal components in CPCs and unmarked objects do not appear in the same structural position.

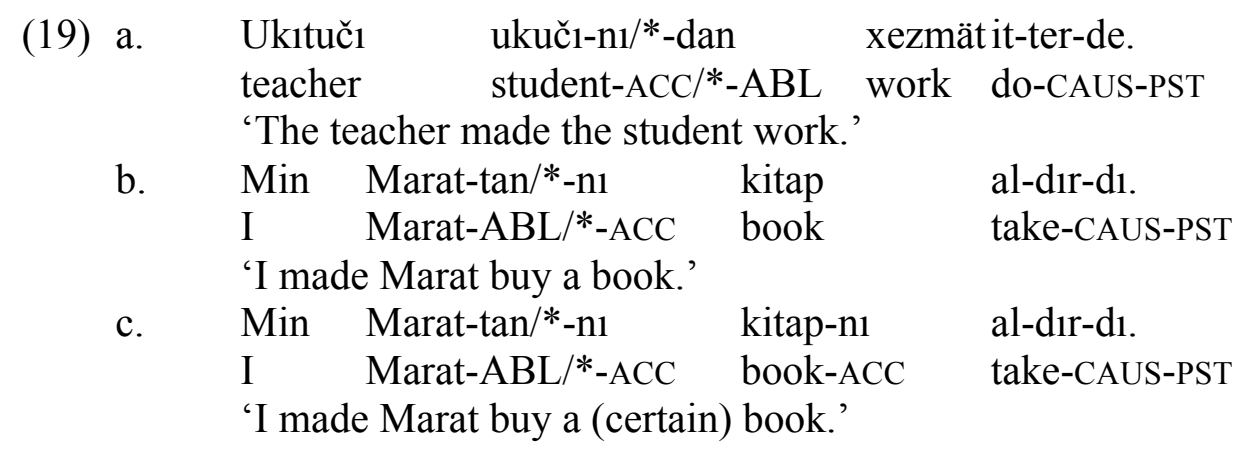




\section{Elucidating Nominal Structure in Tatar}

Second, nominal components in CPCs-like other pseudo-incorporated nominals - cannot be focused by particles such as -gina, whereas unmarked objects can be. For example, the sentence in (20a) can have one of two interpretations, one with focus on the whole verb phrase and the other with focus just on the object. As shown in (20b), the nominal component in CPC cannot be focused by itself.

a. Marat bala-ga jana kitap-kına ukı-dı.
Marat child-DAT new book-EMPH read-PST
'The only thing that Marat did is read the child a new book.'
'Marat read the child only new book.'
äti-se Marat-ka jaya mašina büläk-kına it-te.
father-3 Marat-DAT new car gift-EMPH make-PST
'His father only gave Marat a new car as a gift.'
NOT: \#'His father gave Marat a new car only as a gift.'

Third, unmarked objects can serve as antecedents for discourse anaphora (though not, as you would recall from above, syntactic anaphora), as shown in (21), whereas nominal components in CPCs cannot, as shown in (22). Thus, the second sentence in (22) can mean only that making the student work is useful, not that work itself is useful. The inability to serve as antecedent for discourse anaphora is another hallmark of pseudo-incorporating nominals, suggesting that while nominal components in CPCs are pseudo-incorporated, unmarked objects are not.

$\begin{array}{llrlll}\text { Sin anarga } & \text { kitap } & \text { ala } & \text { ala-sı. } & \\ \text { you } & \text { that.DAT } & \text { book } & \text { take.IPFV } & \text { can.PRS-2SG } & \\ \text { Häm } & \text { a-n } & \text { matur } & \text { it-ep } & \text { ter-ep } & \text { büläk } \\ \text { and that-ACC beautifully } & \text { make-CONV } & \text { wrap-CONV } & \text { gift } \\ \text { it-ergä } & \text { bula. } & & & \\ \text { make-INF } \quad \text { be.PRS } & & & \end{array}$

'You can buy him a book. You can wrap it beautifully and give it to him as a gift.'

(22) Ukıtuč

$\begin{array}{lll}\text { ukučı-nı } & \text { xezmät } & \text { it-ter-de. } \\ \text { student-ACC } & \text { work } & \text { do-CAUS-PST }\end{array}$

teacher

\#UI bik fajdalı eš.

it very useful matter

'The teacher made the student work. It (making the student work) is very useful.'

NOT: 'The teacher made the student work. It (work) is very useful.' 


\section{Ekaterina Lyutikova \& Asya Pereltsvaig}

To recap, contrary to the predictions of the Positional Alternative, ACCmarked objects may appear low in the clausal structure, where they structurally compete with unmarked objects. Moreover, unmarked objects can be shown to not be pseudo-incorporated into the verb, whereas nominal components in CPCs fit the profile of a pseudo-incorporated nominal.

\section{Conclusion: Functional Architecture, Position and Semantics}

In this paper, we argued for the structural analysis of DOM in Tatar whereby DP objects receive structural (accusative) Case, while Small Nominal objects remain Caseless. This serves as an additional argument for the projection of DP in some but not all noun phrases in Tatar, an articleless language. Furthermore, we considered and rejected two alternative approaches to DOM in Tatar: one that places the explanatory burden on the semantics of the object and the other that relies on the position of the object in the clausal structure. We have shown that neither of these alternatives can account fully for the facts concerning DOM in Tatar. The partial overlap between the three possible analyses, however, derives from the fact that Small Nominals lack the DP-layer and consequently lack three things: (a) the semantics of full-fledged DPs (i.e. referentiality), (b) the mobility of full-fledged DPs as they remain invisible to higher Probes searching for $[+\mathrm{D}]$, and (c) the ability to be assigned Case. However, such Small Nominal objects are not as low as pseudo-incorporated nominals, such as the nominal components in CPCs. Moreover, we have shown that full DP objects, which are marked accusative, are not necessarily high in the clausal structure and need not be referential.

\section{References}

Baker, Mark C. 1985. The Mirror Principle and morphosyntactic explanation. Linguistic Inquiry 16:373-416.

Baker, Mark. 2009. Is head movement still needed for noun incorporation? Lingua 119:148-165.

Baker, Mark and Nadya Vinokurova. 2010. Two modalities of Case assignment: Case in Sakha. Natural Language \& Linguistic Theory 28:593-642.

Bošković, Željko. 2005. On the locality of left branch extraction and the Structure of NP. Studia Linguistica 59(1):1-45.

Bošković, Željko. 2008. What will you have, DP or NP? In E. Elfner and M. Walkow, eds., Proceedings of the 37th Annual Meeting of the North East Linguistic Society, 101-114. Amherst, MA: GLSA.

Bošković, Željko. 2009. More on the no-DP analysis of article-less languages. Studia Linguistica 63(2):187-203.

Bošković, Željko. 2010. On NPs and clauses. Ms., University of Connecticut. 


\section{Elucidating Nominal Structure in Tatar}

Bošković, Željko and Serkan Şener. 2012. Turkish NP. Ms., University of Connecticut.

Danon, Gabi. 2006. Caseless Nominals and the Projection of DP. Natural Language and Linguistic Theory 24:977-1008.

Enç, Murvet. 1991. The Semantics of Specificity. Linguistic Inquiry 22:1-26.

Engelhardt, Miriam and Helen Trugman. 1998. D as a Source of Adnominal Genitive in Russian. In Ž. Bošković, S. Franks, and W. Snyder, eds. Formal Approaches to Slavic Linguistics, 114-133. Ann Arbor, MI: Michigan Slavic Publications.

Grashchenkov, Pavel. 2007. Izafetnaja konstruktsija: mnogofaktornyj analiz [Ezafe construction: a multifactorial analysis]. In Misharskij dialect tatarskogo jazyka. Ocherki po sintaksisu i semantike. [Mişär dialect of Tatar. Essays on syntax and semantics]. Kazan': Magarif.

Massam, Diane. 2001. Pseudo incorporation in Niuean. Natural Language and Linguistic Theory 19:153-197.

Pereltsvaig, Asya. 2006. Small nominals. Natural Language and Linguistic Theory 24:433-500.

Pereltsvaig, Asya. 2007. On the Universality of DP: A View from Russian. Studia Linguistica 61(1):59-94.

Pereltsvaig, Asya. 2013. On Number and Numberlessness in Languages without Articles. In Proceedings of BLS 37, 300-314. Berkeley, CA: University of California, Berkeley.

Pereltsvaig, Asya. 2013. Noun Phrase Structure in Article-less Slavic languages: DP or not DP? Language and Linguistics Compass 7(3):201-219.

Pereltsvaig, Asya. forthcoming. On Number and Numberlessness in Languages with and without Articles. In P. Cabredo Hofherr and A. Zribi-Hertz, eds., Languages with and without articles [working title].

Progovac, Ljiljana. 1998. Determiner phrase in a language without determiners. Journal of Linguistics 34:165-179.

Rutkowski, Pawel. 2002. Noun/pronoun asymmetries: evidence in support of the DP hypothesis in Polish. Jezikoslovlje 3:159-170.

Ekaterina Lyutikova

Dept. of Theoretical and Applied Linguistics

Moscow State University

Leninskiye Gory, MSU

$1^{\text {st }}$ Building for Humanities, 953

119991 Moscow

Russia

lyutikova2008@gmail.com 
Ekaterina Lyutikova \& Asya Pereltsvaig

\begin{abstract}
Asya Pereltsvaig
Department of Linguistics

Stanford University

Margaret Jacks Hall

Building 460

Stanford CA 94305-2150
\end{abstract}

asya_pereltsvaig@yahoo.com 